\title{
In the genes or in the stars? Children's competence to consent
}

\author{
Priscilla Alderson Westminster Children's Hospital, London
}

\section{Author's abstract}

Children's competence to refuse or consent to medical treatment or surgery tends to be discussed in terms of the child's ability or maturity. This paper argues that the social context also powerfully influences the child's capacity to consent. Inner attributes and external influences are discussed using an analogy of the genes and the stars.

\section{Emerging competence}

In English law, children under sixteen may refuse or consent to medical treatment if the child is of sufficient understanding to make an informed decision' (1). Although it is preferable to involve their parents, children who, in their doctor's opinion, are competent can give legally effective consent without their parents' knowledge or agreement (2). The law raises questions about the meaning of competence and sufficient understanding. These concepts are often discussed in terms of the child's unfolding nature as if, implicitly, their development is controlled by genes. However, competence is better understood when it is also seen in relation to the child's social context, which will be described using an analogy about stars.

This paper considers a few of the many issues raised in interviews about children's consent during 1989-91 (3). We interviewed 120 patients aged eight to fifteen admitted to four city hospitals for surgery, their parents, and 70 medical and other hospital professionals. They talked about their views on when certain children begin to have sufficient understanding to be able to make sensible decisions about proposed surgery.

Many people seemed surprised to be asked about children's consent and said they had not thought about it. Others at once said: 'Oh yes, I can think of an example at the age of ...', and tell the story of a wise or foolish child. A few said that medical information is too complicated for parents, let alone children, to

\section{Key words}

Children's consent; competence; minors; moral development. understand. Responses ranged from approval of the idea of obtaining children's consent to proposed surgery, usually based on experience of children's competence, or a growing interest in the possibility, to caution, disapproval or, occasionally, outrage. Some people felt that children should be protected from the burdens of decision-making, whereas one surgeon said approvingly: 'Attitudes have changed in the last 20 years. Today's children are given much more freedom, and encouraged not just to do as they are told, but to have strong views.'

The responses fall into three well-established groups: libertarian, protectionist and parentalist (4) Libertarians argue that children should be able to exercise adult rights as soon as they are capable of doing so (5). Protectionists fear the neglect and abuse which inexperienced children might be exposed to, and believe that professionals should intervene to define and protect the child's best interests when necessary. Parentalists say that each child's best interests can only be understood by the 'psychological' parent, the adult closest to that child, who should have the sole control, until the child attains legal maturity (6).

Each view appeared to be determined less by training or logic, than by experience and a disposition to trust or to control children. Some parents said they were stricter with one child than another, because of the child's age or temperament; many spoke of their dwindling powers of protection yielding to the child's growing independence. A few adults felt that, as they gained experience and confidence in their own judgements, they invested more trust in much younger children. Some nurses thought that, as nurses increasingly question medical decisions and act as patients' advocates rather than enforcing compliance, they nurture children's competence. Infants, literally meaning 'without speech', once included legal minors under twenty-one, but now the law requires that very young children's wishes should be ascertained (1).

Children's competence is increasingly discerned at several levels: within each maturing child, in children's changing expectations and in society's growing recognition of children's rights and abilities. The next two parts of this paper consider internal and external influences on competence. 


\section{In the genes}

Many interviewees related competence to partly genetic factors such as intelligence or ability. Discussing the assessment of competence to consent to an operation, one doctor said he would set some simple maths problems. Hospital teachers disagreed, saying they would check on what the child understood about the proposed treatment: 'You'd ask questions to see if they'd made sense of it'. Others, including surgeons and psychologists, said they were guided by the child's own questions, 'whether they ask what's going to happen, and how it might affect them. Are they thinking through what they've been told and its implications?' 'True competence is to answer me back and query things,' said a surgeon who encouraged this response.

Some people were interested in how the child weighed personal with clinical factors. A sister described how seven-year-old Helen (7) summed up the pros and cons of her proposed heart-lung transplant, concluding that she knew the transplant and the treatment afterwards would be very unpleasant, and might not work, and she might die. Yet that would happen to her anyway because her cystic fibrosis was so severe. 'But you did say to me that I might be well enough to ride my pony in a show. So I will have it.' In the sister's view, Helen was so ill that she knew what it meant to face death and to value life far more clearly than any of the adults caring for her could know. This view of children's wisdom was shared by a paediatrician who described the profound awareness which young patients gained through suffering. A hospital chaplain said 'it's not scorable, that kind of wisdom, there are no measures'.

Faced with a mystery, and without objective means of defining or assessing it, adults described their intimations of a child's competence. 'You look them in the eye and watch their responses.' 'You try to get to know them, in the context of their family.' A few adults thought that surgery which required severe long-term follow-up treatment with drugs or physiotherapy had to have the child's willing consent, 'otherwise it's all wasted if they refuse to comply afterwards. Their lives are literally in their own hands'. They would accept the informed refusal of a seriously ill or disabled child aged seven or even five. Healthy young children,or those not affected by their symptoms, were thought to be less able to make informed decisions about vital preventative surgery.

Informed determination was cited as a measure of competence. When eight-years-old, Amy willingly undertook years of painful surgical limb-lengthening treatment. She mentioned a genetic factor which she felt affected consent to immobilising treatment. 'I think it's easier for girls to make this decision, because boys always like rushing about, whereas girls don't mind sitting around so much.'

Personality traits are not listed under the heading of 'genes', obviously personality traits cannot be reduced into solely genetic factors. The heading sums up a particular way of examining people and their inner attributes, such as: gender, ethnicity, temperament and ability, children's level of independence and optimism, their caution or willingness to take risks, their hopes, fears and values. Competence includes having a life-plan, as one doctor said: 'Being able to imagine what it might be like in the future to feel well, or to have a defect corrected, what that might mean to her and how it might change her life'. So Helen thought that the hope of riding her pony validated the risk of surgery, and Amy, who was only a metre high, coped with months of limb-lengthening by 'thinking what it'll be like when I'm taller'. In simple terms they were describing a complex, hard-won understanding of their best interests.

Relying on parents' estimations of their child's competence works well when the child and parents agree. Yet competence only becomes a crucial issue when they disagree. When children arrive at the same decision as the adults, wise maturity may look like compliance or dependence. Conversely children's dissent may be seen as immature folly. Competence is usually called into question during conflict between the child and adults, when stress, anxiety or anger can easily complicate assessments of the child's ability.

Defining competence in terms of personal attributes risks ignoring the social context, and may imply that ability unfolds at its own internal rate, hardly affected by external factors. This approach is strongly? influenced by Piaget's theories that children develop through cognitive stages and cannot grasp certain concepts until they reach the correct stage (8). One of many examples of Piaget's influence on bioethics is the following quotation from bioethicists in 1989 quoting psychologists from 1978 who share Piaget's theories initiated in the 1920s.

'Role-taking skills are also thought to be necessary to enable a child to consider as potentially valid both a position presented to him or her by the physician and his own or her own, different position, so that the alternatives can be weighed against each other. These skills are undergoing substantial development in the eight to eleven age period, and are often quite well developed by twelve to fourteen' (9).

Piaget's theory that children under seven years seldom have 'role-taking skills' was refuted by Scottish researchers in the $1970 \mathrm{~s}(10)$, and by studies of toddlers in the 1980s (11). Strangely, many bioethicists still base their theories on Piaget's, apparently unaware of decades of re-working of his theories and criticisms that they are unduly abstract, concerned only with intellectual development and not with the child's emotions or relationships, or practical, social and imaginative talents $(12,13)$. Piaget tended to perceive the universal child as isolated, autonomously working out individual conclusions, unaffected by race, class, poverty, illness or disability. Such abstraction 
characterises mainstream bioethics, which perhaps accounts for Piaget's lasting influence. The bioethics example quoted earlier continued by defining competence as a set of mechanistic skills including the ability to concentrate, 'to weigh more than one treatment alternative and set of risks simultaneously (ie cognitive complexity), ability to abstract or hypothesise as yet non-existent risks and alternatives and ability to employ inductive and deductive reasoning ... and abstract concepts in problem solving' (14). It is questionable how expert in these skills children or adults need be to qualify as competent, and whether people actually think in this way. The philosophers label young children as 'incompetents' because they are supposed to be incapable of 'cognitive complexity', to have unstable, transient values, no real concept of 'the good', of death, of their future, or of their likely future values (15).

Yet empirical research shows, for example, profound understanding of death in children aged five years (16). Everyday evidence also refutes the bioethicists' assumptions, such as when an average nine-year-old watches soap operas like 'Eastenders'. Each series shows a large cast connected by confusing inter-marriage and inter-generational networks, and longstanding friendships and feuds, grappling with a constant onslaught of ethical dilemmas. One example is a black headmistress deciding whether to abort her fetus diagnosed as having sickle cell anaemia. Her husband, a church elder, threatens to leave her because he cannot accept abortion. Her children anxiously await her decision.

A further complication is that each scenario lasts only a few seconds. Someone drowning fades into a scene of a teacher reprimanding pupils, followed by an argument about rain forests, and other complex encounters, then back to the drowning. Each series demands acute observation, rapid interpretation of numerous understated details, sophisticated knowledge of wide-ranging social issues, and formidable powers of concentration, association and memory. Otherwise each episode is a bewildering, boring kaleidoscope. Yet when anyone uninitiated wanders past and asks 'Who's this? Why are they doing that?' children can discuss the biography and motives of anyone in the cast. Our interviews with almost every patient had to be fitted around sacrosanct soap opera times.

Children's cognitive development is not as inexorably slow as Piaget believed, nor does their thinking fit the abstracted list quoted earlier. Risk and benfit concern actual or potential experiences, and are understood through the imagination, a potent skill in children, but one not mentioned in the list. Children's well developed sense of morality and justice is shown, for instance, in their response to Blue Peter appeals and their interest in ecology. Many children adopt lasting moral values, and little is known about how rare or common are precocious examples, such as Dante's life-long passion which began when he was nine.
Apart from underestimating children's abilities, Piagetian psychology and the bioethics based on it take the individual as the unit of analysis; competence is then seen as a mechanical skill or quality, isolated from the social context. Yet competence is understood by seeing the child's inner, partly genetic abilities in relation to external influences, as considered in the next section.

\section{In the stars}

Men at some time are masters of their fates:

The fault, dear Brutus, is not in our stars,

But in ourselves, that we are underlings (17).

When Cassius debates the power of free will versus fate, and of ourselves versus our circumstances, Shakespeare makes him favour modern individualism over mediaeval astrology. Yet the stars he mentions provide an analogy for the social context in which children try to search for explanations and to exert competent control over their fate.

The mediaeval universe consisted of concentric rings, like the solar system, but with the stars and planets circling the earth. The geocentric model fits children's competence for several reasons. We think of the sun as the central source of light, and of enlightened adult reasoning as the centre ofo intelligence. However, understanding children's? competence entails questioning adult-centred thought and looking at how things fit together and make sense from the child's lower, more earth-bound perspective. The solar system revolves around the sun's gravitational force, but in the pre-Newtonian universe, all the stars followed their own path.Although the caring adults in hospital take the child as their centre of concern, they follow their own trajectories and volition, and to the child their courses can seem mysterious, erratic, and far beyond the patient's control.

Power and energy in the solar system radiate outwards from the central sun to the dark planets, but the mediaeval stars exerted their powerful astrological influence down onto the earth. Similarly, the child, although often at the centre of attention, is largely under the influence of the surrounding adults and events. The final reason for choosing a prescientific mediaeval metaphor is to emphasise that the image is no more than a metaphor, a device to help to explain reality, unreal in itself and only partly apposite. Piaget described his theories as real, and directly reflecting 'actual psychological activities' in the child's mind (18). They have been used almost as facts on which to found bioethics theories. But it is important to remember how little we know about children and how all images and theories are only attempts to describe something approximate to their worlds.

So in the centre of the framework, like the half-lit earth, is the child's understanding, surrounded by 
star-like influences such as the home and family, school and friends, disease and treatment, health professionals and hospital. Beyond, are wider forces: the current state of medicine, the law, the media and concepts of childhood.

\section{HOME AND FAMILY.}

Younger children depend on their parents to interpret and explain medical details. A psychologist we interviewed thought that a three-year-old understood the purpose and nature of his liver biopsy as well as some adults would, because his mother, a nurse, explained it so carefully. A boy with muscular dystrophy learns much about his future from his older brother and friends who have the same disease. Each family's way of discussing or secreting information, and sharing or fighting over decisions, will also affect their response to medical decisions.

Parents affect the child's maturity when they reward or punish growing independence. Ann Solberg's research with hundreds of Norwegian twelve-year-olds shows that children whose parents expect them to be responsible respond well, and are entrusted with more and more adult responsibilities (19). Yet children whose parents perceive them as immature remain so, their resistance being perceived as foolish or rebellious. Competent children usually know adults who nurture their abilities, treating them as mature people. Competence is a way of relating to others, not simply an individual skill.

Kohlberg's stages of moral development towards an isolated, abstract adult morality (20) reflect Piaget's and Erikson's stage theories about adolescents' increasingly isolated autonomy (21). These are challenged by Gilligan (22) and by Apter's research with mothers and daughters (23), in which many mothers said: 'We must be very unusual, instead of growing apart during her adolescence I find we're much closer'. Moral dilemmas do not all end in a correct, logical solution borne in lonely autonomy; there are often risks and benefits in each solution. None is perfectly correct, and intense disputes, as well as splitting them apart, can draw families into closer solidarity, which enriches the child's autonomy. Amy's mother dreaded the family disruption which years of leg-lengthening would entail, but supported Amy's decision to the extent of giving up her own career in order to nurse her. Another mother commented: 'In the end, your children have to live their own lives, and you have to let them make their mistakes and help them to make the best of it'. Many of our interviewees identified maturity with more equal and detailed discussion. Mothers would say: 'If I needed an operation, I'd always want to it talk over with my family first, and we'd come to some kind of decision. I wouldn't just decide on my own'.

Social class, family income, ethnicity, the number of children in the family, the parents' age and education, and other factors in the home and family can all affect decision-making.

\section{THE HOSPITAL}

Children having surgery are cared for by many adults who move, like mediaeval stars, in a pattern that is believed to be co-ordinated, although the design is not always understood or entirely benign. The quality of patients' consent is influenced by the design of wards and clinics, and whether there is space to sit and talk quietly. Multi-professional teams give different kinds of information, in a mosaic which sometimes overlaps, and has gaps and contradictions (24). Information for children varies, some being clear and relevant, practical and visual and play specialists create ingenious aids which help children to understand complex treatment.

Some of the surgeons in our study explained many details; a few surgeons thought this only confused and frightened families. Their patients might appear to be incompetent because they had not been informed. Children are more likely to be able to consent to elective treatment for a chronic condition, than during an unexpected emergency. The seven wards in which we interviewed were all different; some were warmly welcoming and the nurses spent much time informing, supporting and listening to children, offering them choices and encouraging them to take an active part in their treatment. These are a few of the ways that children's competence is influenced in hospital.

\section{MEDICINE}

Children's competence is also affected by the current and ever-changing state of medicine, which determines the kinds of procedures that consent will be sought for. As new techniques are refined, uncertainty is replaced by well-researched data about risks and prognoses. When surgeons are well informed, patients can be too. As new skills reduce patients' discomfort and danger, information can be more reassuring, and it is therefore easier for adults to inform children.

Professionals learn from listening to children, and by appreciating, for instance, that they can experience intense pain (25). As a result, pain control is improved. Some children we interviewed used patient-controlled analgesia pumps or practised their own hypnotherapy, methods which literally put the child in charge. When patients are assured that pain can be relieved, consenting to surgery becomes less of an ordeal. A child who is too young to decide whether to have surgery, may be able to decide about gradually reducing the analgesia dosage. Encouraging children to share in making many interim decisions during their treatment respects their competence.

Among countless changes in medicine is the growing interest in patients' consent, which relates to the next public influence on competence.

\section{THE LAW}

Centuries of Hippocratic paternalism in medicine were recently challenged by legal traditions almost as ancient of self-determination. The ensuing conflict has 
been described almost in terms of the collision of two great stars (26). Rising rates of litigation have led to speculation as to whether the power of the courts will eclipse the power of the medical profession. Lawyers also influence medical decisions through research ethics committees, American review boards, and when children are made wards of court during disputes about surgery or child abuse. The law has implications for children's competence throughout the twentiethcentury debate on adult patients' consent. Children's legal status has also generally changed, as they are entitled to a growing set of legal rights, including the right, if competent, to make major personal decisions.

During the 1980s, research into children as witnesses in court investigated their abilities to recall and recount events under stress, and to distinguish reality from fantasy. Researchers have also examined egocentricity as a moral and cognitive weakness in child witnesses. Some researchers conclude that the real danger of egocentrism may be that of the interviewing adult who is unable to appreciate the child's view (27). The findings, that even preschool children can be reliable witnesses when they are treated considerately, suggest that as anxious patients they are also likely to be able to understand and remember more information than used to be thought possible. The child's status is changing within the medico-legal context surrounding surgery.

\section{THE MEDIA}

The media expand children's knowledge, partly because the visual presentation of complex issues attracts their interest. The media present many role models of articulate young people asserting their rights, arguing a case clearly, expecting high standards from shops and public services, and generally taking charge of their own lives, in ways that would astonish Piaget. Television's admiration for young people bravely fighting illness and disability perhaps exaggerates real-life trends towards fuller equality between doctors and patients, and thus may encourage child patients to expect to be treated with respect.

\section{CHILDHOOD}

Childhood as an institution (not individual children) is a set of beliefs and practices determining how children are treated and how they respond. It differs radically in time and place; people aged twelve years are treated as responsible adults in one society and as fairly helpless dependants in another. The quite recent Western custom of excluding all children from the work-force and putting them into school offers them benefits and disadvantages.

For street-wise Victorian children, 'whatever the compensation, the school put these children into the servitude of a repressive innocence and ignorance' (28). We have inherited a Victorian tendency to confuse ignorance with innocence although, as Blake's pre-Victorian reflections on childhood illustrate, the two qualities are very different (29). This confusion leads many adults to want to protect children from harsh realities, such as knowledge of their serious illness. Yet children are frequently aware of the truth and may have joined a collusion of silence to try to protect their parents (30). Avoiding discussion can be convenient for adults but less so for children if it denies them informed choice.

Adults who assess competence are inevitably affected by the child's nervous or friendly response to them, and by their own prejudices. These include a permissive or controlling attitude, and current beliefs about British children's abilities in the 1990s, which can clarify or obscure recognition of the child's actual competence. Beliefs about childhood also influence whether adults inform children and encourage them to take decisions, and whether children want and feel able to learn, choose and act. For some of the young patients we met, surgery was a time of learning, maturing and gaining confidence, so that the results of tests of competence would vary from week to week; people are not static. The care of children in hospital is affected as much by changing beliefs about childhood, as by the changing medico-legal context.

Many factors surround children's consent, and powerfully, often invisibly, influence the child's understanding and decisions. Some of the young patients we met wanted to 'be the main decider', others wanted to share in decisions, and others wanted their parents and/or doctors to make decisions for them. Competence is more than a skill, it is a way of relating, and can be understood more clearly when each child's inner qualities are seen within a network of relationships and cultural influences.

\section{Acknowledgement}

I thank everyone who helped in the children's consent research project, my co-researcher Jill Siddle, the Leverhulme Trust and the Alder Hey Children's Hospital Trust Fund for sponsorship.

Priscilla Alderson, $B A, P h D$, is a Research Sociologist in the Community Paediatric Research Unit at the Westminster Children's Hospital, London SWIP 2NS.

\section{References}

(1) Children Act 1989 c41 pt4 6 is applied to all children by the Department of Health. Welfare of children and young people in hospital, London: HMSO, 1991.

(2) The Law Lords' ruling in Gillick $v$ West Norfolk and Wisbeach AHA [1985] 3 All ER is repeated in the Department of Health's guide: see reference (1).

(3) Alderson P. Children's consent to surgery. Milton Keynes: Open University Press, (in press).

(4) Franklin R, ed. The rights of children. Oxford: Blackwell, 1986; Richards M, Light P, eds. Children of social worlds. Cambridge, Mass: Harvard University Press, 1986.

(5) Holt J. Escape from childhood. Harmondsworth: Penguin, 1975.

(6) Goldstein J, Freud A, Solnit A. Beyond the best interests of the child, 1973; Before the best interests of the child. New 
York: Free Press, 1979.

(7) The children's names are changed.

(8) Piaget J. The child's construction of reality. London: Routledge, 1958.

(9) Buchanan A, Brock D. Deciding for others: the ethics of surrogate decision making. New York: Cambridge University Press, 1989: 220, quoting Grisso T, Vierling L. Minors' consent to treatment: a developmental perspective. Professional psychology 1978; 9: 412-427.

(10) Donaldson M. Children's minds. Glasgow: Fontana, 1978.

(11) Dunn J, Kendrick C. Siblings: love, envy and understanding. Cambridge, Mass: Harvard University Press, 1982.

(12) Bradley B. Visions of infancy: a critical introduction to child psychology. Cambridge: Polity Press, 1989.

(13) See reference (4): Richards $M$, Light $P$, eds.

(14) Quoted from reference (9). Similar views appear in Gaylin W, Macklin R, eds. Who speaks for the child? New York: Plenum Press, 1982; Melton G, Koocher G, Saks $\mathrm{M}$, eds. Children's competence to consent. New York: Plenum Press, 1983; Kopelman L, Moskop J, eds. Children and health care: moral and social issues. Dordrecht: Kluwer, 1989.

(15) See reference (9): $220 \mathrm{f}$.

(16) Such as Bluebond-Langner M. The private worlds of dying children. New Jersey: Princeton University Press, 1978; Lansdown R, Benjamin G. Concepts of death. Childcare health and development 1985; 11: 13-19.

(17) Shakespeare W. Fulius Caesar. 1: ii.
(18) Piaget J. Logic and psychology. New York: Basic Books, 1957: 7.

(19) Solberg A. Negotiating childhood. In: James A, Prout A, eds. Constructing and reconstructing childhood. Basingstoke: Falmer Press, 1990.

(20) Kohlberg L. The philosophy of moral development. San Francisco: Harper and Row, 1981.

(21) Erikson E. Identity: youth and crisis. New York: Norton, 1968.

(22) Gilligan C. In a differeni voice. Cambridge, Mass: Harvard University Press, 1982.

(23) Apter T. Altered loves: mothers and daughters during adolescence. Hemel Hempstead: Wheatsheaf Harvester, 1990.

(24) Alderson P. Choosing for children: parents' consent to surgery. Oxford: Oxford University Press, 1990.

(25) Royal College of Surgeons, College of Anaesthetists. Pain after surgery. London, 1990.

(26) Katz J. The silent world of doctor and patient. New York: Free Press, 1984.

(27) Spencer J, Flin R. The evidence of children: the law and psychology. London: Blackstone Press, 1990.

(28) James A, Prout A, eds. Constructing and reconstructing childhood. Basingstoke: Falmer Press, 1990.

(29) Blake W. Songs of innocence. 1789; Songs of experience. 1794. Harmondsworth: Penguin, 1958.

(30) Kubler-Ross E. On children and death. Basingstoke: Macmillan, 1983. See also reference (16): BluebondLangner.

\section{News and notes}

\section{Call for abstracts}

An international conference on chronic diseases and changing care-patterns in an ageing society will be held in Amsterdam, the Netherlands from 9-11 June 1993.

Topics on both somatic and psychiatric chronic conditions will be covered. Abstracts on the following topics are invited: epidemiological issues; care issues; psychological and social issues; policy issues; economic issues; ethical and legal issues. Abstracts must be submitted by October 311992.

Keynote speakers include Dr Trudi van den Bos,
Dr Jacob A Brody, Dr Alain Colvez, Dr Robbert Huijsman, Dr Louise J Gunning-Schepers, Dr Henk J J Leenen, Dr John B McKinlay, Dr S Jay Olshansky, Dr Walter W Rosser and Dr Lois $M$ Verbrugge.

For further details and information on submission and format of abstracts please write to: Dr Trudi van den Bos or Wien Limburg, Institute of Social Medicine, University of Amsterdam, Meibergdreef 15, $1105 \mathrm{AZ}$ Amsterdam, the Netherlands. Tel: ../31 20.5664707; fax: ../31 20.6912401. 